\title{
ELSEVIER_JCRP_3585
}

\section{Population dynamics of Meloidogyne javanica and its relationship with the leaf chlorophyll content in zucchini}

\section{López-Gómez ${ }^{2}$}

E. Flor-Peregrin

\section{Talavera ${ }^{\mathrm{b}}$}

F.J. Javior Sorribas ${ }^{c}$

S. Verdejo-Lucas ${ }^{\mathrm{a} *}$ *

aIRTA, Sustainable Plant Protection Program, Crta. de Cabrils Km 2, 08348, Cabrils, Barcelona, Spain

bIFAPA, Centro Camino de Purchil, Camino de Purchil s/n, 18004, Granada, Spain

cDepartament d'Enginyeria Agroalimentària i Biotecnologia, Universitat Politècnica de Catalunya, Esteve Terradas 8, 08860, Castelldefels, Barcelona, Spain

*Corresponding author. Present address: IFAPA, Centro La Mojonera, Camino de San Nicolás 1, 04745, La Mojonera, Almería, Spain.

\section{Abstract}

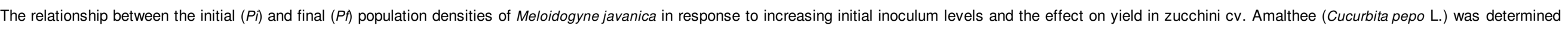

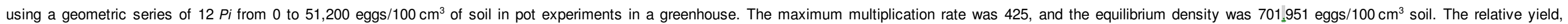

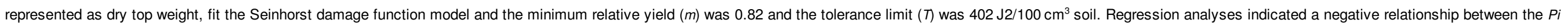

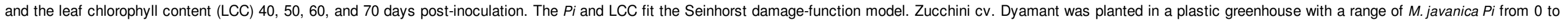

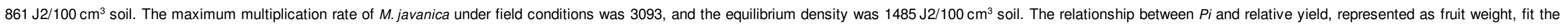
Seinhorst damage function model $\left(P<0.0001, R^{2}=0.78\right) ; m$ was 0.48 , and $T$ was $0.02 \mathrm{~J} 2 / 100 \mathrm{~cm}^{3}$ soil.

Keywords: Cucurbita pepo; Root-knot nematode; Damage functions

\section{Introduction}

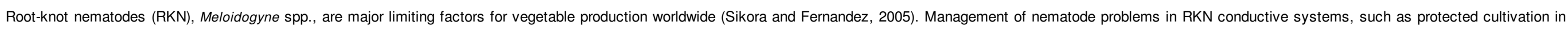

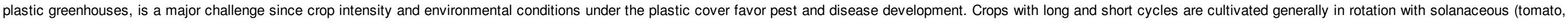
pepper and eggplants) and cucurbitaceous (cucumber, melon, watermelon, and zucchini) crops with short fallowing periods (4_8 weeks) between successive crops (Sorribas and Verdejo-Lucas, 1994; Talavera et al., 2012).

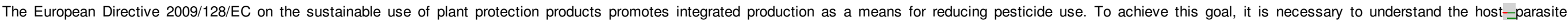

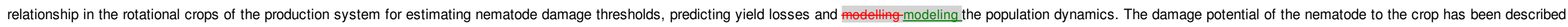

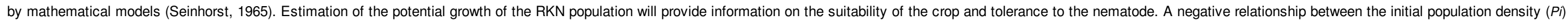

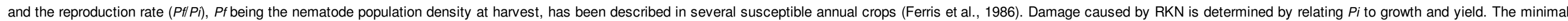

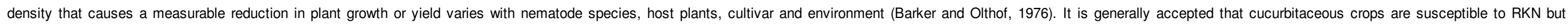

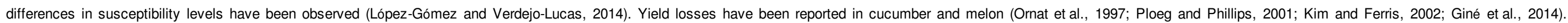
However, few studies have focused on the development of damage-functions models for zucchini, Cucurbita pepo L. (Ferris et al., 1986; Vela et al., 2014).

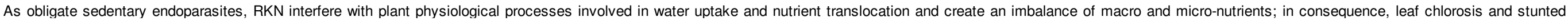




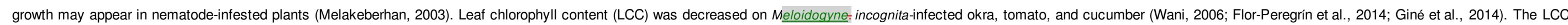

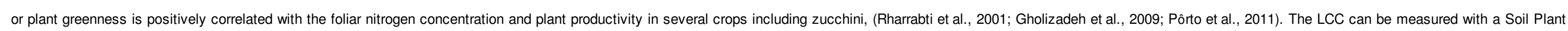

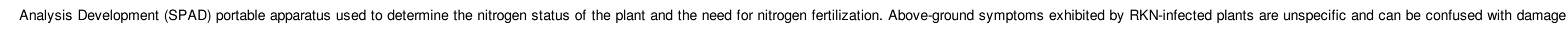

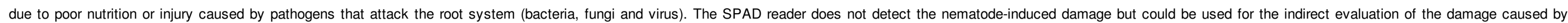
nematodes when they are present. However, it should be used with care because other factors may influence the health of the plants.

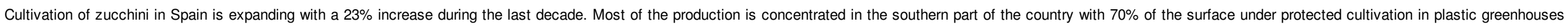

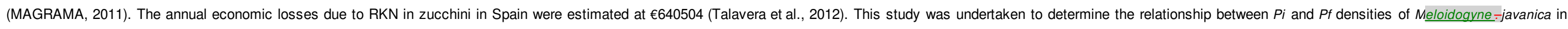
zucchini, the yield losses in response to increasing initial inoculum levels and to assess the relationship between Pi and LCC, as an indirect indicator of nematode-induced damage.

\section{Materials and methods}

\subsection{Pot experiments}

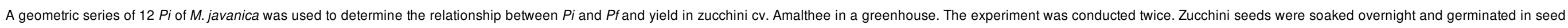

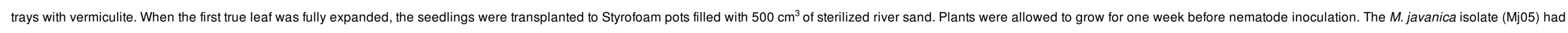

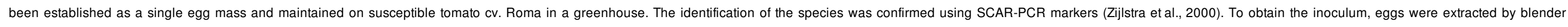

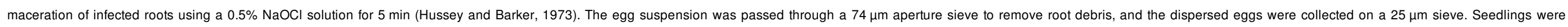

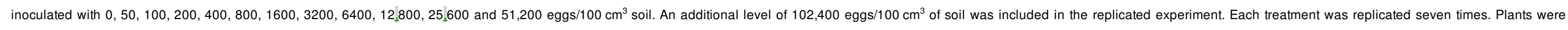

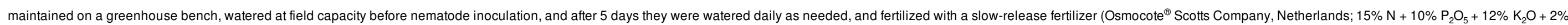

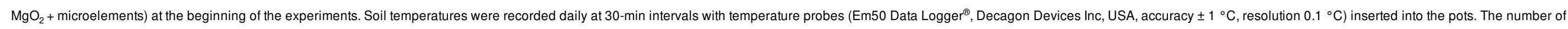
M. javanica generations was calculated according to $\mathrm{Tb}=10.8^{\circ} \mathrm{C}$ and 526 accumulated degree-days (DD) (Vela et al., 2014).

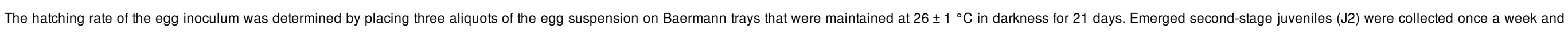
stored at $4{ }^{\circ} \mathrm{C}$ until counted. The hatching rate (\%) was then calculated and the egg inoculum converted to number of emerged $\mathrm{J} 2$ that represented the effective inoculum for root invasion.

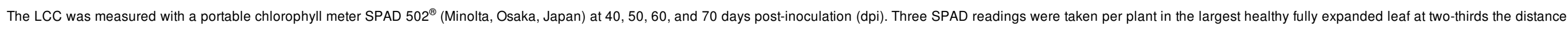
from the leaf tip towards the stem.

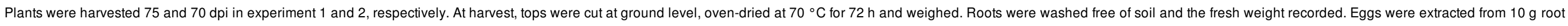
subsamples using $0.5 \% \mathrm{NaOCl}$ solution for $10 \mathrm{~min}$ as described previously and quantified (eggs and egg shells). The $P i$ is expressed as the number of emerged $\mathrm{J} 2 / 100 \mathrm{~cm}^{3} \mathrm{soil}$ and the $P f$ as the total number of eggs $/ 100 \mathrm{~cm}^{3}$ soil.

\subsection{Field experiments}

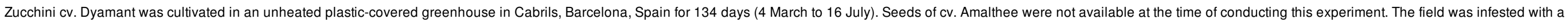

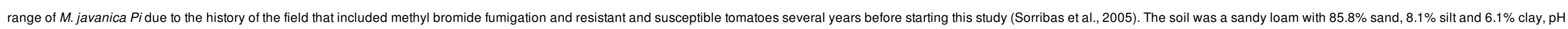

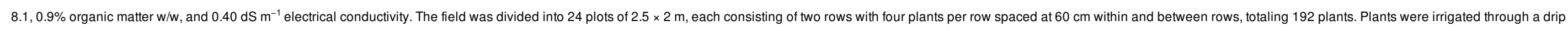
irrigation system and fertilized once a week.

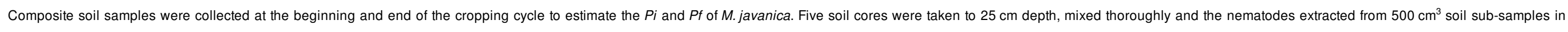

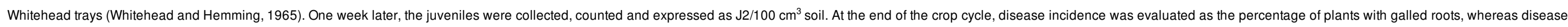

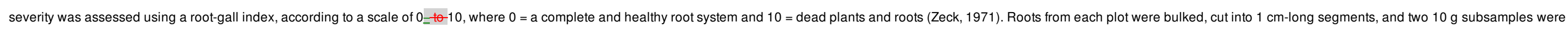
used to extract eggs by blender maceration in a $0.5 \% \mathrm{NaOCl}$ solution for $10 \mathrm{~min}$ as described above. The number of eggs was expressed per gram fresh root weight.

Fruits were collected weekly for six weeks, weighed and the cumulated yield expressed as g/plant. 


\section{ELSEVIER_JCRP_3585}

\subsection{Statistical analyses}

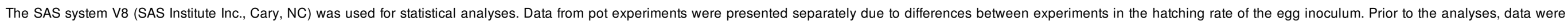

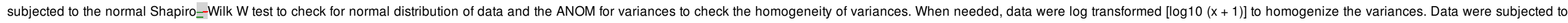

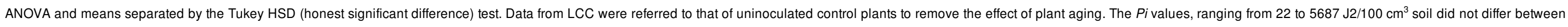

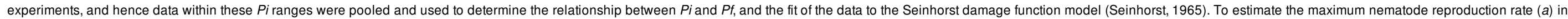

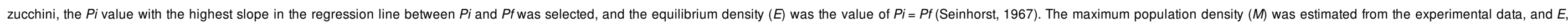

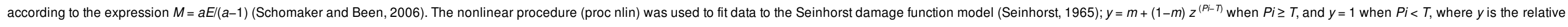

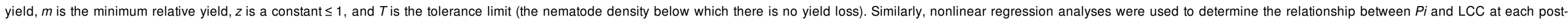

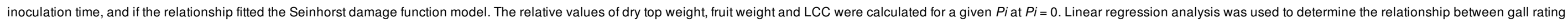
and yield in the field experiment.

\section{Results}

\subsection{Pot experiment}

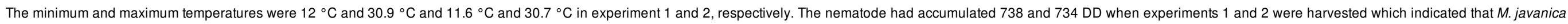

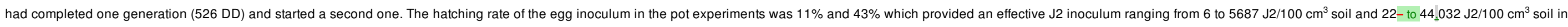

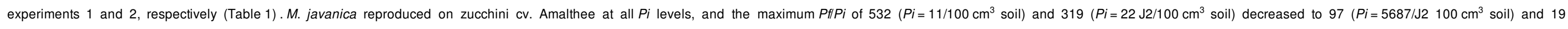

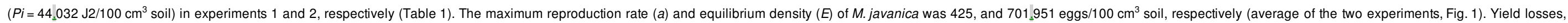
represented as dry top weight, fit the Seinhorst damage function $\left(P<0.005, R^{2}=0.49\right)$, showing that $m$ was 0.82 and $T$ was $402 \mathrm{~J} 2 / 100 \mathrm{~cm}^{3}$ soil (Fig. 2).

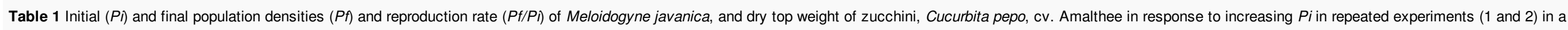
greenhouse.

\section{$\operatorname{Pi}\left(\mathrm{J} 2 / 100 \mathrm{~cm}^{3}\right.$ soil)} $2 \pm 4 \mathrm{e}$ $6 \pm 1.7 \mathrm{e}$ $10 \pm 2 \mathrm{e}$ $16 \pm 3$ e $36 \pm 6 \mathrm{e}$ $67 \pm 12$ de $35 \pm 6 \mathrm{e}$ $266 \pm 18 \mathrm{~cd}$ $359 \pm 51 \mathrm{bc}$ $755 \pm 11 \mathrm{a}$

$547 \pm 97 \mathrm{ab}$
Pf $\times 10^{3} / 100 \mathrm{~cm}^{3}$ soil

2

$7 \pm 0.9 \mathrm{c}$

$10 \pm 1.7 \mathrm{c}$

$19 \pm 2 \mathrm{c}$

$28 \pm 1 \mathrm{c}$

$61 \pm 9 \mathrm{c}$

$112 \pm 24 \mathrm{C}$

$184 \pm 26 \mathrm{c}$

$646 \pm 42 \mathrm{ab}$

$505 \pm 54 \mathrm{~b}$
$P f / P i$

1

428 a

532 a

460 a

$366 \mathrm{ab}$

$413 \mathrm{a}$

$379 \mathrm{ab}$

$99 \mathrm{bc}$

$378 \mathrm{ab}$

$255 \mathrm{abc}$

$268 a b c$

$97 \mathrm{bc}$

0

$5.1 \pm 0.3 \mathrm{a}$

319 a

$238 \mathrm{ab}$

$223 a b$

$163 \mathrm{bc}$

$177 \mathrm{bc}$

162 bc

$134 \mathrm{bcd}$

$235 \mathrm{ab}$

$97 \mathrm{cde}$

\section{$5.4 \pm 0.4 \mathrm{a}$}

$5.8 \pm 0.4 \mathrm{a}$

$6.1 \pm 0.8$ a

$5.5 \pm 0.4 \mathrm{a}$

$5.3 \pm 0.4 \mathrm{a}$

$6.1 \pm 0.9 a$

$4.1 \pm 0.3 \mathrm{ab}$

$5.1 \pm 0.3 \mathrm{a}$

$3.8 \pm 0.3 \mathrm{~b}$

$4.3 \pm 0.3 \mathrm{ab}$
Dry top weight (g)

1
$4 \pm 0.5 \mathrm{ab}$

$3.9 \pm 0.3 \mathrm{ab}$

$4.3 \pm 0.3 \mathrm{ab}$

$4.4 \pm 0.3 \mathrm{a}$

$4.1 \pm 0.3 \mathrm{ab}$

$4.3 \pm 0.3 \mathrm{ab}$

$3.4 \pm 0.2 \mathrm{ab}$

$4.2 \pm 0.2 \mathrm{ab}$

$3.3 \pm 0.3 \mathrm{ab}$

$3.5 \pm 0.3 \mathrm{ab}$ 


\section{ELSEVIER_JCRP_3585}

$P i\left(\mathrm{~J} 2 / 100 \mathrm{~cm}^{3}\right.$ soil)

Days-post-inoculation

40

\begin{tabular}{|l|l|}
\hline 0 & $1 \mathrm{abc}$ \\
\hline $6^{*}$ & $1 \pm 0.04 \mathrm{a}$ \\
\hline $11^{*}$ & $1 \pm 0.02 \mathrm{a}$ \\
\hline 22 & $1 \pm 0.05 \mathrm{ab}$ \\
\hline 45 & $1 \pm 0.04 \mathrm{ab}$ \\
\hline 90 & $1 \pm 0.09 \mathrm{ab}$ \\
\hline 181 & $0.98 \pm 0.03 \mathrm{abc}$ \\
\hline 361 & $0.92 \pm 0.04 \mathrm{bcd}$ \\
\hline 723 & $0.94 \pm 0.04 \mathrm{a}=\mathrm{d}$ \\
\hline 1446 & $0.90 \pm 0.04 \mathrm{~b}=\mathrm{e}$ \\
\hline 2893 & $0.84 \pm 0.03 \mathrm{c}-\mathrm{f}$ \\
\hline 5687 & $0.81 \pm 0.03 \mathrm{def}$ \\
\hline $11_{\perp} 008^{*}$ & $0.71 \pm 0.03 \mathrm{ef}$ \\
\hline $22_{\perp} 016^{*}$ & $0.65 \pm 0.04 \mathrm{f}$ \\
\hline $44_{-} 032^{*}$ & $0.68 \pm 0.03 \mathrm{f}$ \\
\hline
\end{tabular}

\begin{tabular}{|l}
$1 \pm 0.02 \mathrm{a}$ \\
$0.96 \pm 0.03 \mathrm{a}$ \\
$0.96 \pm 0.03 \mathrm{a}$ \\
$0.93 \pm 0.03 \mathrm{ab}$ \\
$0.86 \pm 0.03 \mathrm{a}=\mathrm{e}$ \\
$0.87 \pm 0.03 \mathrm{a}=\mathrm{d}$ \\
$0.75 \pm 0.03 \mathrm{c}=\mathrm{g}$ \\
$0.80 \pm 0.02 \mathrm{~b}-\mathrm{f}$ \\
$0.80 \pm 0.04 \mathrm{a}=\mathrm{f}$ \\
\hline $0.73 \pm 0.05 \mathrm{~d}=\mathrm{h}$ \\
$0.58 \pm 0.06 \mathrm{gh}$ \\
$0.63 \pm 0.03 \mathrm{fgh}$ \\
\hline $0.61 \pm 0.04 \mathrm{fgh}$ \\
\hline $0.65 \pm 0.08 \mathrm{e}=\mathrm{h}$ \\
$0.52 \pm 0.04 \mathrm{~h}$
\end{tabular}

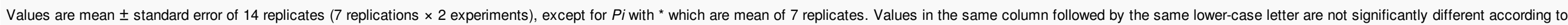
Tukey HSD (Honestly Significant Difference).

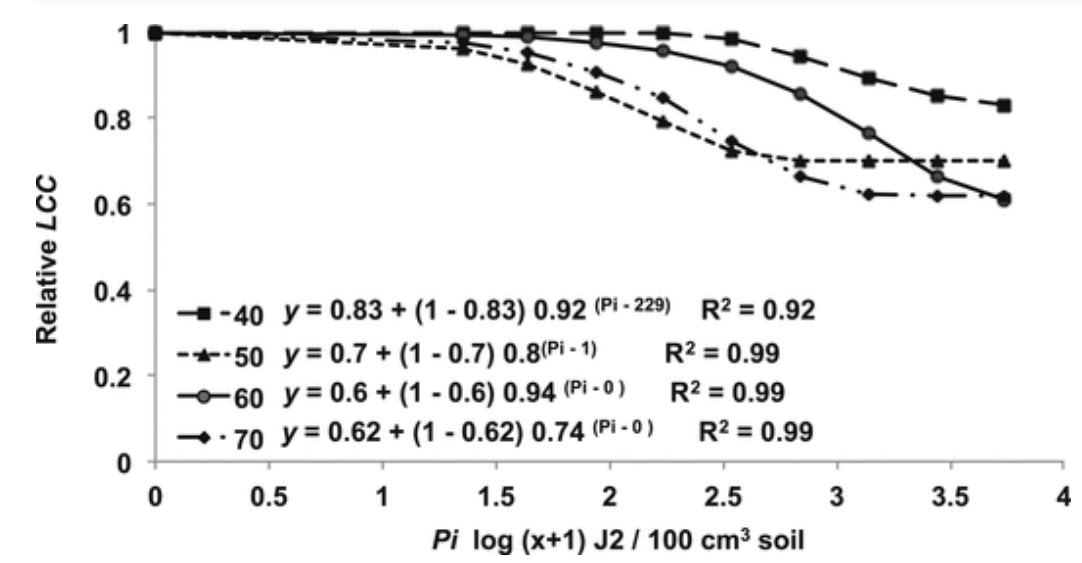

Fig. 3 Relationship between Meloidogyne javanica initial population densities $(P I)$ and relative leaf chlorophyll content (LCC) measured at 40,50,60, and 70 days post inoculation in pot experiments in a greenhouse. Values are means of 14 replicates/treatment.

\subsection{Field experiment}

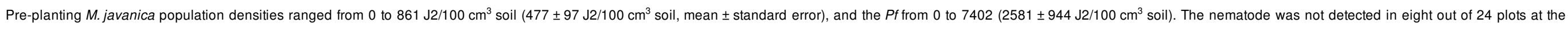

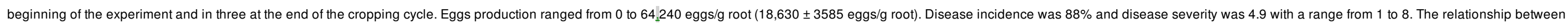




\section{ELSEVIER_JCRP_3585}

Values of yield are mean \pm standard error of $n$ plants.

${ }^{a}$ Based on a scale of 1 to-10 (Zeck, 1971)

\section{Discussion}

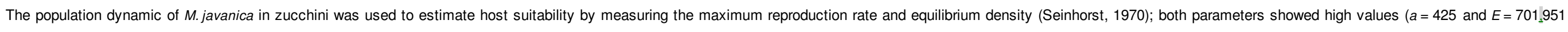

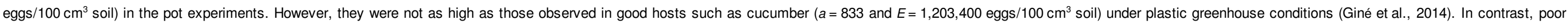

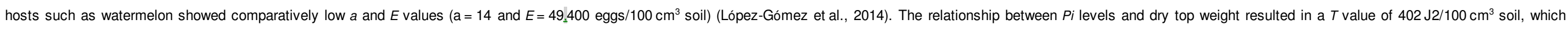

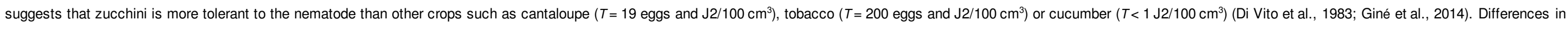

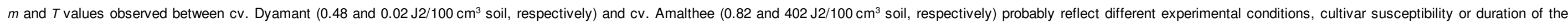

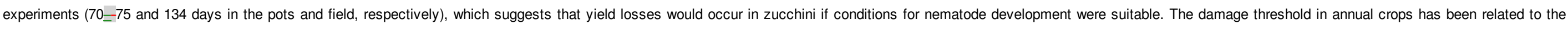

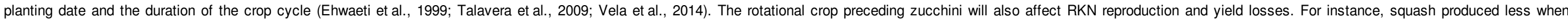

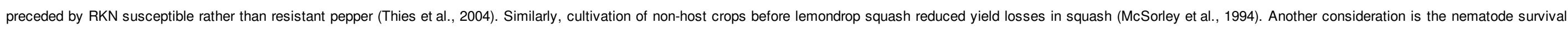
rate during the short fallow periods between successive crops estimated in 50\% of the $P f$ of the preceding crop (Ornat et al., 1999).

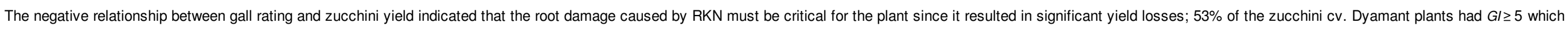

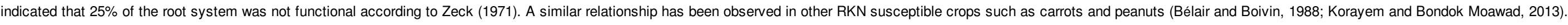

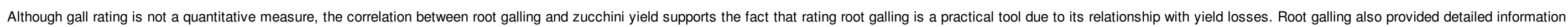
on the spatial distribution of the nematode in the field and the identification of areas of severe disease symptoms that could allow the construction of a reference map to document the crop history of the site.

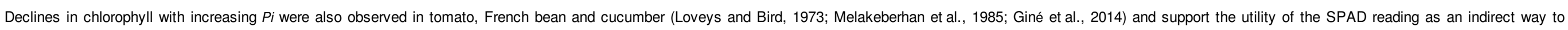

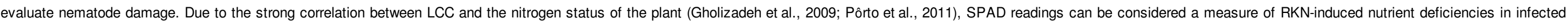

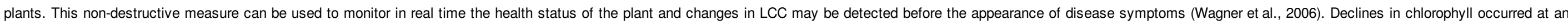

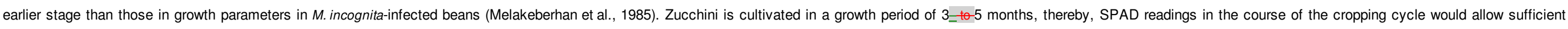

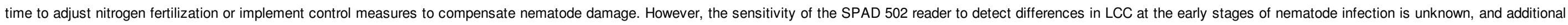

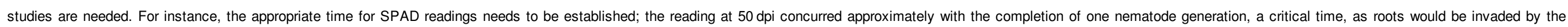
second nematode generation.

\section{Conclusions}

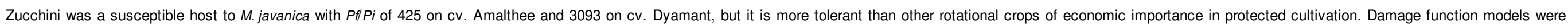

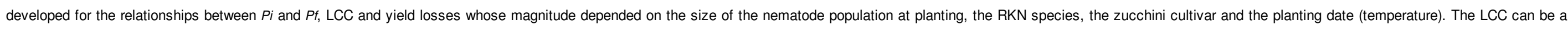

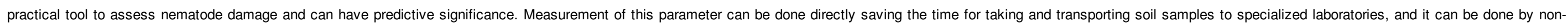
skilled personnel with brief elementary training.

\section{AcknowledgementAcknowledgment}

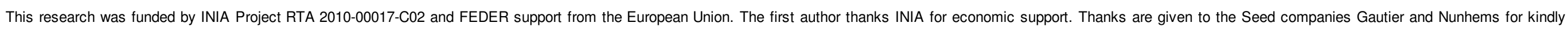
providing seeds. The assistance of Maria Blanco, Victoria Barnés, Olga Gonzalez and Olga Jurado in plant care and nematode extractions is much appreciated.

\section{References}

Barker K.R. and Olthof T.H.A., Relationship between nematode population densities and crop responses, Annu. Rev. Phytopathol. 14, 1976, 327-353.

Bélair G. and Boivin G., Spatial pattern and sequential sampling plan for Meloidogyne hapla in muck-grown carrots, Phytopathology 78, $1988,604-607$. 


\section{ELSEVIER_JCRP_3585}

Di Vito M., Greco N. and Carella A., The effect of population densities of Meloidogyne incognita on the yield of cantaloupe and tobacco, Nematol. Medit. 11, 1983, 169-174.

Ehwaeti M.E., Fargette M., Phillips M.S. and Trudgill D.L., Host status differences and their relevance to damage by Meloidogyne incognita, Nematology 1, 1999, 421-432.

Ferris H., Ball D., Beem L.W. and Gudmundson L.A., Using nematode count data in crop management decisions, Calif. Agric. 40, 1986, 12-14.

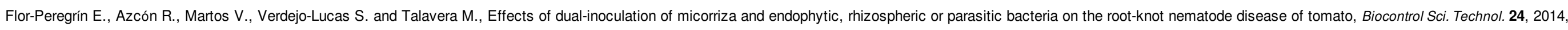
$1122-1136$.

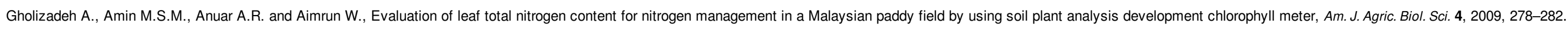

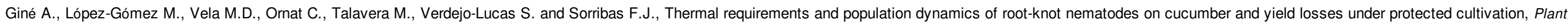
Pathol. 63, 2014, 1446-1453.

Hussey R.S. and Barker K.R., A comparison of methods of collecting inocula of Meloidogyne spp., including a new technique, Plant Dis. 57, 1973, 1025-1028.

Kim D.G. and Ferris H., Relationship between crop losses and initial population densities of Meloidogyne arenaria in winter-grown oriental melon in Korea, J. Nematol. 34, $2002,43-49$.

Korayem A.M. and Bondok Moawad M.M.M., Damage threshold of root-knot nematode, Meloidogyne arenaria on peanut in relation to date of planting and irrigation system, Can. J. Plant Prot. 1, 2013, 117-124.

López-Gómez M. and Verdejo-Lucas S., Penetration and reproduction of root-knot nematodes on cucurbit species, Eur. J. Plant Pathol. 138, $2014,863-871$.

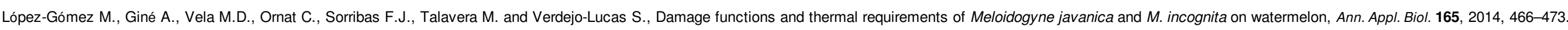

Loveys B.R. and Bird A.F., The influence of nematodes on photosynthesis in tomato plants, Physiol. Plant Pathol. 3, 1973, 525-529.

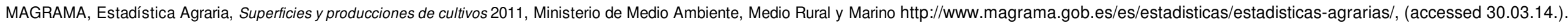

McSorley R., Dickson D.W., De Brito J.A. and Hochmuth R.C., Tropical rotation crops influence nematode densities and vegetable yields, J. Nematol. 26, 1994, 308-314.

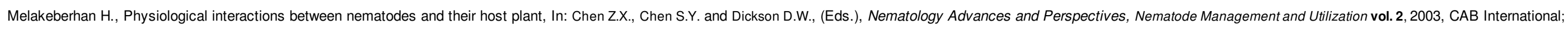

Wallingford, UK, 771-794.

Melakeberhan H., Webster J.M. and Brooke R.C., Response of Phaseolus vulgaris to a single generation of Meloidogyne incognita, Nematologica 31, 1985, 190-202.

Ornat C., Verdejo-Lucas S. and Sorribas F.J., Effect of the previous crop on population densities of Meloidogyne javanica and yield of cucumber, Nematropica 27, 1997, 85-90.

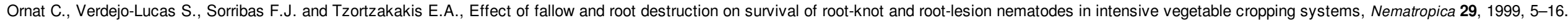

Ploeg A.T. and Phillips M., Damage to melon (Cucumis melo L.) cv. Durango by Meloidogyne incognita in Southern California, Nematology 3, 2001, 151-157.

Pôrto M.L., Puiatti M., Fontes P.C.R., Cecon P.C., Alves J.C. and Arruda J.A., Índice SPAD para o diagnóstico do estado de nitrogênio na cultura da abobrinha, Hortic. Bras. 29, 2011, 311-315.

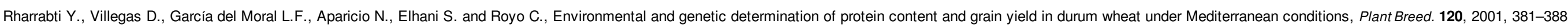
Schomaker C.H. and Been T.H., Plant growth and population dynamics, In: Perry R.N. and Moens M., (Eds.), Plant Nematology, 2006, CAB International; Wallingford, 275-295.

Seinhorst J.W., The relation between nematode density and damage to plants, Nematologica 11, 1965, 137-154.

Seinhorst J.W., The relationships between population increase and population density in plant parasitic nematodes. II. Sedentary nematodes, Nematologica 13, 1967, 157-171.

Seinhorst J.W., Dynamics of populations of plant parasitic nematodes, Annu. Rev. Phytopathol. 8, 1970, 131-156.

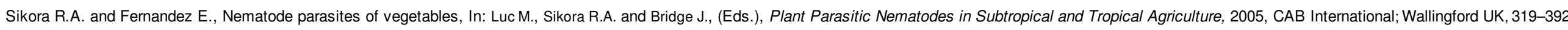




\section{ELSEVIER_JCRP_3585}

Sorribas F.J. and Verdejo-Lucas S., Survey of Meloidogyne spp. in tomato production fields of Baix Llobregat county, Spain, J. Nematol. 26, 1994, 731-736.

Sorribas F.J., Ornat C., Verdejo-Lucas S., Galeano M. and Valero J., Effectiveness and profitability of the Mi-resistant tomatoes to control root-knot nematodes, Eur. J. Plant Pathol. 111, 2005, 29-38.

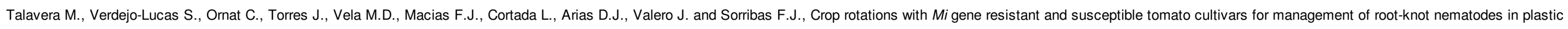
houses, Crop Prot. 28, 2009, 662-667.

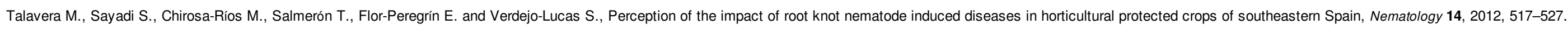
Thies J.A., Davis R.F., Mueller J.D., Fery R.L., Langston D.B. and Miller G., Double-cropping cucumbers and squash after resistant bell pepper for root-knot nematode management, Plant Dis. 88, 2004, 589-593.

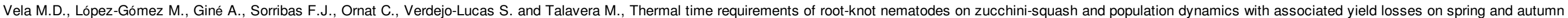
cropping cycles, Eur. J. Plant Pathol. 140, 2014, 181-490

Wagner A., Michalek W. and Jamiolkowska A., Chlorophyll fluorescence measurements as indicators of fusariosis severity in tomato plants, Agro. Res. 4, $2006,461-464$.

Wani A.H., Management of root-knot nematode, Meloidogyne incognita, on okra and mung by soil amendment with oil cakes and leaves of different plants, Nematol. Medit. 34, 2006, 83-87.

Whitehead A.G. and Hemming J.R., A comparison of some quantitative methods of extracting small vermiform nematodes from soil, Ann. Appl. Biol. 55, 1965, 25-38.

Zeck W.M., A rating scheme for field evaluation of root-knot nematode infestations, Pflanzenschutz-Nachr. Bayer. Ag. 24, 1971, 141-144.

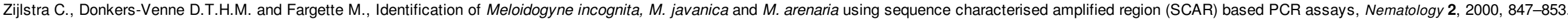

Highlights

- Zucchini squash showed tolerance to Meloidogyne javanica in protected cultivation.

- The leaf chlorophyll content declined with increasing initial population densities.

- The leaf chlorophyll content can be a practical tool to assess nematode damage.

- Root damage caused by M_toidoge javanica was directly related with yield losses.

- Zucchini yield was significantly reduced in heavily infected plants.

\section{Queries and Answers}

Query: Please check that the affiliations link the authors with their correct departments, institutions, and locations, and correct if necessary.

Answer: Everithing is correct

Query: Please check the address for the corresponding author that has been added here, and correct if necessary.

Answer: Everything is correct

Query: Please provide the grant number for 'European Union' if any.

Answer: Not exist grant number

Query: Please confirm that given names and surnames have been identified correctly. 
Answer: It has been corrected

\section{ELSEVIER_JCRP_3585}

